\title{
A közúti közlekedés természetkárosító hatása a magyarországi gerincesfaunára - Szakirodalmi áttekintés
}

\author{
Borza Sándor ${ }^{1,2,3^{*}}$, Godó Laura ${ }^{1}$, Csathó András István ${ }^{4}$, \\ Valkó Orsolya ${ }^{1}$ és Deák Balázs ${ }^{1}$ \\ ${ }^{1}$ Ökológiai Kutatóközpont, Ökológiai és Botanikai Intézet, Lendület Vegetáció és \\ Magbank Dinamikai Kutatócsoport, 2163 Vácrátót, Alkotmány út 2-4. \\ ${ }^{2}$ Debreceni Egyetem, Juhász-Nagy Pál Doktori Iskola, 4032 Debrecen, Egyetem tér 1. \\ ${ }^{3}$ Hortobágyi Nemzeti Park Igazgatóság, 4024 Debrecen, Sumen u. 2. \\ ${ }^{4}$ Független kutató, 5830 Battonya, Somogyi Béla u. 42/A \\ ${ }^{*}$ E-mail: borzas89@gmail.com
}

\begin{abstract}
Összefoglaló: A közlekedés a civilizáció mindennapos velejárója, működésének egyik legfontosabb alappillére. Az elmúlt évtizedekben világszerte jelentős mértékben növekedett az úthálózatok hoszsza és a forgalomban levő gépjármüvek száma. A közlekedési infrastruktúra terjeszkedése, valamint a megnövekedett forgalom amellett, hogy megnövekedett környezeti terheléshez és az élöhelyek fragmentációjához vezet, jelentősen növeli az állatok gépjárművekkel történő ütközésének esélyét is. Vizsgálatunkban összegyüjtöttük a magyarországi vonatkozású publikációkat annak érdekében, hogy rámutassunk a közúti közlekedésnek a kétéltü-, hüllő-, madár- és emlős-populációkra kifejtett káros hatásaira. Az irodalmi áttekintés során 41 közleményt találtunk, amelyekben 153 gerincesfaj pusztulását regisztrálták a szerzők. Eredményeink rámutatnak, hogy közúti gázolások következtében milliárdos nagyságrendủ természetvédelmi kár keletkezett, és keletkezik jelenleg is a magyarországi gerincesfaunában.
\end{abstract}

Kulcsszavak: állat-gépjármü ütközés, gépkocsik által elütött állatok, természetvédelmi kár, élőhely-fragmentáció, természetvédelem, Amphibia, Reptilia, Aves, Mammalia

\section{Bevezetés}

A közúti közlekedés a modern társadalom múködésének elengedhetetlen részét képezi, ugyanakkor súlyos terhet ró a szárazföldi ökoszisztémákra. Amellett, hogy a közlekedés során káros anyagok millió tonnái kerülnek nap mint nap a légkörbe, a megépített utak és a közúti forgalom jelentős közvetett és közvetlen hatást fejtenek ki a vadon élő gerinces- és gerinctelen-állatközösségekre (van der 
Ree et al. 2015). Az úthálózatok terjeszkedésének egyik jelentős következménye, hogy a korábban összefüggő természetes élőhelyek feldarabolódtak. A globális úthálózat mintegy 600000 fragmentumra darabolta fel a természetes élőhelyeket, és a létrejött élőhelytöredékek több mint a fele kisebb, mint $1 \mathrm{~km}^{2}$, és csak a 7\%-a nagyobb, mint $100 \mathrm{~km}^{2}$ (Ibisch et al. 2016). A közúti forgalomban közlekedő gépjármüvek száma is jelentős mértékben megnövekedett az elmúlt évtizedekben. Míg 1976-ban csak 342 millió regisztrált gépjármü volt világszerte, addig 1996-ban 670 millió és 2016-ban már 1,32 milliárd volt ez az érték (http1). Ezekből a számokból jól kivehető, hogy húszévente gyakorlatilag megduplázódik a forgalomban közlekedő gépjármüvek mennyisége. Magyarországon, ha nem is volt ilyen drasztikus a növekedés, de 2001 és 2020 között 2,97 millióról 4,75 millióra nőtt a gépjárművek száma (http2). Ezt pedig csak tetézi az a tény, hogy a magyarországi közúti forgalomban több millió külföldi gépjármü is megfordul évente (http2). Ezeknek a civilizációs hatásoknak köszönhetően egyre fokozódó konfliktushelyzet alakult ki az ember és az állatvilág között. A konfliktusok egyik fő forrása a vadon élő állatok elütéséből származik, amely évtizedek óta növekvő tendenciákat mutat (van der Ree et al. 2015).

Hill és munkatársai (2019) megállapították, hogy a vadászat után a második legjelentősebb ember által okozott mortalitási tényező a gerincesek vonatkozásában a gépjármüvek általi elütés. A nemzetközi szakirodalomban már a 20. század elejétől kezdve közöltek esetleírásokat a témában. Az első nagyléptékü felmérést 1935-ben végezték, aminek eredményeképpen 940 elütött madár tetemét regisztrálták 6400 kilométernyi felmért angliai útszakaszon (Barnes 1936). Az első, országos léptékü vizsgálat szintén Nagy-Britanniában volt az 1960-as évek elején, ahol önkénteseket is bevontak az adatgyüjtésbe. A kutatás során megállapították, hogy hozzávetőlegesen 2,5 millió madár és félmillió emlös pusztult el a brit közutakon a felmérés egy éve alatt (Hodson és Snow 1965). Európa több országában, illetve a tengerentúlon is készítettek hasonló felméréseket a gázolásokkal kapcsolatosan (1. táblázat). Schwartz és munkatársai (2020) szerint évente az elütések miatt elpusztult gerincesek becsült száma meghaladja a 400 millió egyedet világszinten.

Annak ellenére, hogy Magyarországon nem készült országos szintü becslés, itt sem ismeretlen ez a természetvédelmi és vadgazdálkodási probléma. A témában az első magyarországi közlés Träger Józseftől származik, amely a Madártani Tájékoztató címü folyóiratban jelent meg (Träger 1978). Az első szisztematikusan végzett, minden gerinces-osztályra kiterjedő vizsgálatot Onuczán József végezte 1989-1990-ben (Onuczán 1992). Gazdag Ferenc vezetésével egy fél éven át múködő monitoring programban 5880 kilométernyi felmért útszakaszon 45 gerincesfaj 955 elgázolt egyedét regisztrálták, ami az akkori jogszabályokban 
1. táblázat. Az elérhető országos állat-gépjármü ütközés becslések eredményei (millió egyed/év) (Schwartz et al. 2020).

\begin{tabular}{ccccc}
\hline & Kétéltü & Madár & Emlös & Összes gerinces \\
\hline Ausztrália & 5 & - & - & - \\
Belgium & - & - & - & 4 \\
Brazília & - & 8,4 & 2,2 & - \\
Bulgária & - & 5 & - & - \\
Dánia & - & - & - & 8,3 \\
Finnország & - & - & - & 6,5 \\
Hollandia & - & 2 & 0,2 & - \\
Kanada & - & 13,8 & - & - \\
Németország & - & - & - & 32 \\
Spanyolország & - & - & - & 10 \\
Svédország & - & 8,5 & 0,2 & - \\
USA & - & 340 & - & - \\
\hline
\end{tabular}

meghatározott természetvédelmi értékekkel számolva 3,6 millió forintnyi természetvédelmi kárt eredményezett (Gazdag 2007, 2008). Mivel a közepes és nagytermetü emlőseink fokozott közlekedésbiztonsági kockázatot jelentenek a közúti forgalomban közlekedők számára, ezért ezekkel a fajokkal már többen is foglalkoztak részletesebben. Már több mint húsz éve folyamatosan gyüjtik a közúti elütési adatokat a vadászható fajokról a Magyar Vadelhullás Monitoring keretében (Faragó és László 2002). Cserkész és munkatársai (2012, 2013) a magyarországi autópályákon bekövetkezett emlősgázolásokat monitorozták éveken keresztül annak érdekében, hogy meghatározzák a problémás gyorsforgalmi útszakaszokat. Akadt olyan kutatás is, amely több évtizedes távlatban zajlott regionális léptékben. Csathó András István és Csathó András János több mint húsz éves adatsorral rendelkezik Battonya település közigazgatási határán belül, aminek eredményeképpen már több ezer állatgázolással kapcsolatos megfigyelést dokumentáltak (Csathó és Csathó 2009, 2014).

Irodalmi áttekintésünk célja, hogy összefoglaljuk a gerincesek gépjárművekkel történő ütközéséről a magyar szakirodalomban szórványosan közölt eredményeket. Célunk volt, hogy ezen adatok felhasználásával elkészítsük a Magyarország területén közúti forgalomban dokumentáltan elpusztult gerincesek fajlistáját, és becslést tegyünk az eddigi dokumentált elütések során keletkezett természetvédelmi kár mértékére. Tekintettel arra, hogy a korábban közölt elütési adatok nagyon eltérő módszertannal kerültek rögzítésre, és a legtöbb esetben ezek a tanulmá- 
nyok csupán fajlistákat közöltek, így jelen tanulmánynak nem célja a nagyléptékü következtetések levonása, mintázatok feltárása. Ugyanakkor a szerzők bíznak abban, hogy egy magyarországi léptékü irodalmi áttekintés és a legveszélyeztetettebb gerincescsoportok azonosítása hozzájárulhat a probléma megértéséhez, és alapot adhat jövőbeli szisztematikus felmérések elindításához.

\section{Anyag és módszer}

Az irodalmi áttekintés során elsődlegesen azokra a közleményekre fókuszáltunk, amelyekben természetvédelmi oltalom alatt álló, nem vadászható gerincesek elütési adatait közölték. A vadászható vadfajokra kidolgozott monitoring-rendszer viszonylag pontos becslést ad a vadelütések mértékéről (Faragó és László 2002), ám mivel cikkünk elsődleges célja a természetvédelmi kár becslése, ezért ezen fajok elütési adatait nem használtuk fel az összesítéseknél (azokat kizárólag csak a fajlistában soroltuk fel). Első lépésként részletesen áttekintettük a magyar nyelvü tudományos közleményeket, valamint az angol nyelvü, de magyarországi vonatkozású publikációkat is. A keresésekhez a Magyar folyóiratok tartalomjegyzékeinek kereshető adatbázisa (http3), a Google Scholar (http4), illetve a Web of Science (http5) weboldalakat használtuk. A keresések időintervalluma az első magyarországi publikáció megjelenésétől (1978) 2020-ig terjedt. A lektorált publikációkon felül az irodalmi áttekintésünkbe bevontuk az elérhető könyvfejezeteket, illetve konferenciaabsztraktokat is. Mivel ezen közlések nem szerepelnek az online adatbázisokban, sok esetben nehezen fellelhetőek, illetve nem elérhetőek, így lehetséges, hogy egyes közlések nem szerepelnek a tanulmányunkban. Minden általunk ismert elérhető forrást feldolgoztunk, és felhasználtuk az elütésekkel kapcsolatos publikált adatokat (faj, egyedszám). Ezen adatsorok felhasználásával elkészítettük a Magyarországról közölt elütési adattal rendelkező gerincesállatfajok listáját rendszertani osztályonkénti lebontásban. Meghatároztuk az ezek alapján eddig keletkezett természetvédelmi kár összegét fajonként. A kár összegének kiszámításához a jelenleg hatályban álló jogszabályban közzétett természetvédelmi értékeket használtuk fel (6/2015. (X. 26.) FM rendelet). Az elütések osztályok szerinti megoszlását azon publikációk alapján határoztuk meg, melyek a felmérés során az összes gerinces-osztályt számba vették.

\section{Eredmények}

A szakirodalmi áttekintés eredményeként 41 közleményt gyüjtöttünk össze, amelyekben állat-elütésekkel kapcsolatos tényszerủ közlések voltak (1. Online Füg- 
gelék). Szerkezetüket és tartalmukat illetően nagy különbségek voltak az egyes közlések között. A tanulmányok között voltak egy fajjal kapcsolatos adatközlések, de találtunk komplex, mind a négy érintett gerinces-osztályt felölelö felmérést is. Több esetben a publikációk nem tartalmaztak részletes adatokat az elütött fajokról és az egyedszámokról. A legtöbb közlés a madarakra fókuszált, őket követték az emlősök, a hüllők, majd a kétéltűek. Általános, minden gerinces-taxonra kiterjedő adatgyüjtéssel hat közlemény foglalkozott részleteiben, de a mintavételezés módja (felmért útszakasz hossza, felmérési alkalmak száma) jelentősen eltérő volt. Az osztályok között a legtöbb elütött egyed a kétéltüek közül került ki, míg a legkevesebb a hüllők közül került elő. Továbbá a magyarországi fauna viszonylatában az elütött fajok számának aránya is a kétéltủek osztályában volt a legmagasabb (1. ábra).

A közlések száma jelentős térbeli eltéréseket mutatott. A közölt adatok alapján elmondható, hogy a legtöbb állat-gázolással kapcsolatos forrás Pest és Békés megyéből származott, míg a legkevesebb Vas megyéből (2. ábra). Az összesített adatok szerint összesen 153 gerincesfaj egyedei estek dokumentáltan közúti gázolás

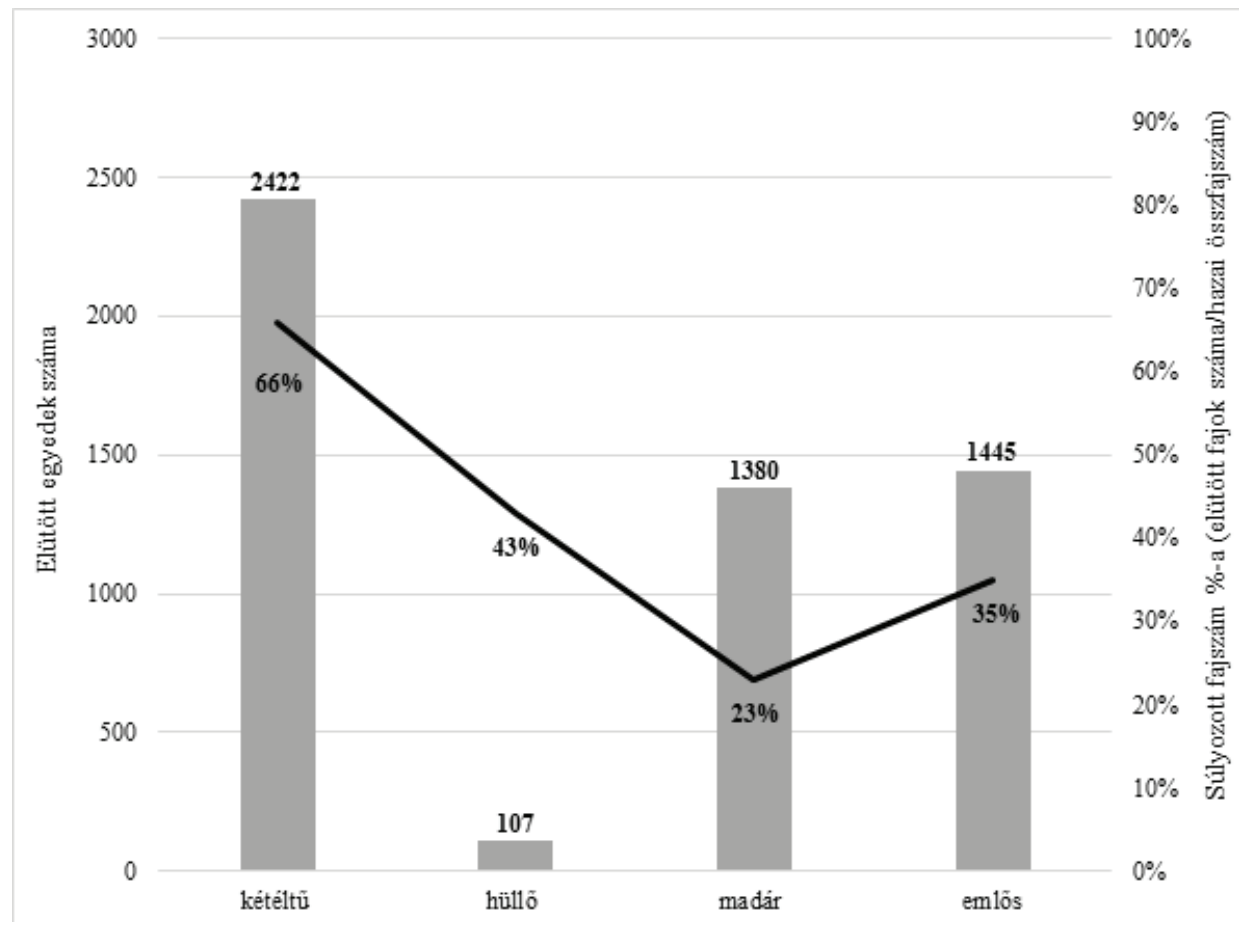

1. ábra. Az elütött gerinces-egyedek rendszertani osztályonkénti bontása a teljes, mind a négy taxonra kiterjedő felmérések eredményének tükrében (Träger 1978, Krug 1983, Fenyves 1989, Onuczán 1992, Gazdag 2007, Csathó és Csathó 2009), valamint az összesített adatok alapján kalkulált bizonyítottan elütést szenvedett fajok száma a magyarországi faunakészlet viszonylatában. 


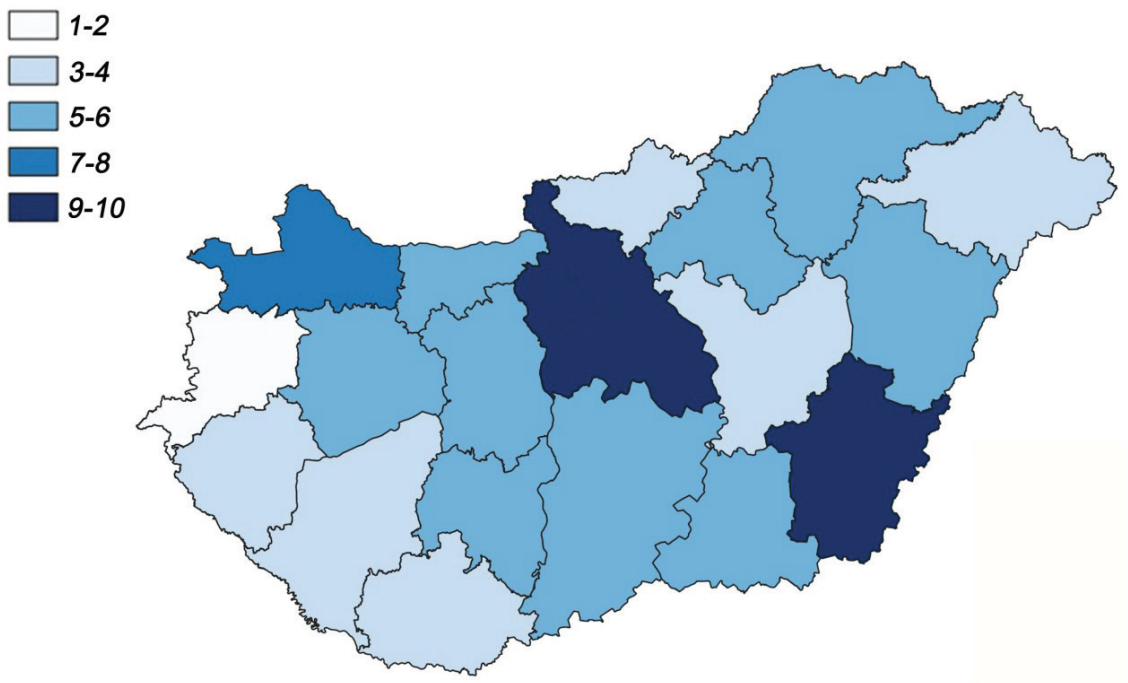

2. ábra. Az állat-elütésekkel kapcsolatos közlések megyénkénti megoszlása.

áldozatául Magyarországon (2. Online Függelék). Ezek közül 130 faj áll természetvédelmi oltalom alatt, és 19 faj fokozottan védett státuszú (66/2015. (X. 26.) FM rendelet). A dokumentáltan keletkezett természetvédelmi kár meghaladta a 2,6 milliárd forintot, amelynek a döntő része a kétéltüek osztályához köthető. A madarak és emlösök esetében voltak elérhetőek a legpontosabb adatok, amelyek alapján a közölt természetvédelmi kár értéke ezen két osztály esetében meghaladja a 180 millió forintot. Fontos hangsúlyozni, hogy a közölt természetvédelmi kár minden esetben becsült érték, a valódi kár minden bizonnyal több nagyságrenddel nagyobb, tekintettel arra, hogy nem a teljes országra kiterjedő, szisztematikusan gyüjtött adatsorokon alapul a becslés.

\section{Kétéltüek (Amphibia)}

A témában hét publikációt találtunk. Mivel a többi taxonhoz képest a kétéltüek élőhelyigénye specifikusabb, ezért az elütések számos esetben bizonyos lokalitásokhoz kötődtek (például vizes élőhelyek környezete), ahol azonban tömeges pusztulás volt tapasztalható. A gázolások tekintetében a legkritikusabb periódus a tavaszi és az őszi szezon, amikor a kétéltúfajok egyedei nagy csapatokban vonulnak a telelö- és szaporodóhelyük között (Endes 1990, Puky 1987). Ha ezeket a vonulási folyosókat közutak keresztezik, az a kétéltủ-populációk jelentős 
csökkenéséhez vezethet (Pallag 2000). Frank és munkatársai (1991) szerint az 1990-es évek elején a Fertő tó térségében egy vonulási periódus alatt 100000 és 200000 közötti egyedszámban pusztultak el kecskebékák - Pelophylax k1. esculentus (Linnaeus, 1758) - és kis tavibékák - Pelophylax lessonae (Camerano, 1882). Mivel a két faj természetvédelmi értéke azonos (10 000 forint), ezért faji szintü elkülönítés nélkül is megállapítható a természetvédelmi kár értéke, amely jelen esetben 1-2,2 milliárd forint közötti összeg volt. Puky (1987) hasonló problémára hívta fel a figyelmet a barna varangy - Bufo bufo (Linnaeus, 1758) - esetében a Börzsöny hegységet átszelő 2. számú fouút vonatkozásában, illetve beszámolt az aktív természetvédelmi mentőakció sikerességéröl is.

\section{Hüllök (Reptilia)}

A hüllők közúti gázolásával kapcsolatban tíz közleményt találtunk. Ennél a taxonómiai csoportnál is elmondható, hogy részben kötődnek bizonyos élőhelytípusokhoz (például egyes fajok vizes élőhelyekhez), így az elütések eloszlása is változó. Nagyobb mértékủ pusztulást csak a vízisiklónál (Natrix natrix Linnaeus, 1758) közöltek. Frank és munkatársai (1991) 1000 elhullott egyedet regisztráltak a Fertő tó térségében a tavaszi és őszi vonulás során, míg Szabolcs és munkatársai (2014) szintén 1000 egyed feletti elhullást dokumentáltak a Bodrogzugban. Molnár és Andrési (2019) szerint Magyarországon az egyik leggyakoribb elütött hüllőfaj a mocsári teknős (Emys orbicularis Linnaeus, 1758), köszönhetően lassú mozgásának. A magyarországi gyíkfajok közül csak a fürge gyík (Lacerta agilis Linnaeus, 1758) és a zöld gyík (Lacerta viridis Laurenti, 1768) gázolási adatait említették az áttekintett források (Puky et al. 2005, Pallag 2000).

\section{Madarak (Aves)}

A közúti forgalomban áldozatul esett madarakról 23 publikációt találtunk a magyarországi szakirodalomban. A madarak osztályának fajai a legtöbb élőhelyen előfordulnak, így elütött egyedeik nem mutatnak a kétéltüekhez és hüllőkhöz hasonló térbeli aggregációt. A publikált 99 faj közül a leggyakoribb áldozatok az énekesmadarak közül kerültek ki, de a ragadozómadarak és a vízimadarak közül is több fajt regisztráltak a szerzők. Az elütött madarak legnagyobb része Magyarországon költő faj volt, átvonuló és telelő fajok elütését csak kisebb számban regisztrálták. A publikált adatok szerint Magyarországon a leggyakrabban elgázolt madár a házi veréb (Passer domesticus Linnaeus, 1758) 535 dokumentált elütött egyeddel (2. táblázat).

A napjainkig közölt adatok alapján 91 természetvédelmi oltalom alatt álló madárfaj esett áldozatul gépjármügázolásnak Magyarországon, amiből 15 fokozottan védett státuszú. A több mint 2000 egyedet meghaladó pusztulásból adódóan 
2. táblázat. A tíz leggyakrabban elgázolt madárfaj Magyarországon a publikált adatok alapján.

\begin{tabular}{ccc}
\hline Magyar név & Tudományos név & Elütött egyedek száma \\
\hline Házi veréb & Passer domesticus & 535 \\
Mezei veréb & Passer montanus & 393 \\
Tövisszúró gébics & Lanius collurio & 277 \\
Füsti fecske & Hirundo rustica & 245 \\
Fenyőpinty & Fringilla montifringilla & 237 \\
Molnárfecske & Delichon urbicum & 216 \\
Tengelic & Carduelis carduelis & 167 \\
Kuvik & Athene noctua & 101 \\
Fekete rigó & Turdus merula & 69 \\
Gyöngybagoly & Tyto alba & 66 \\
\hline
\end{tabular}

93 millió forintnyi természetvédelmi kár keletkezett. A legnagyobb dokumentált természetvédelmi kárt elszenvedett madárfaj a füsti fecske (Hirundo rustica Linnaeus, 1758) volt 245 egyeddel, amelynek a pénzben kifejezett természetvédelmi értéke meghaladja a 12 millió forintot (3. táblázat). A természetvédelmi szempontból legértékesebb fajok között volt a fekete gólya - Ciconia nigra (Linnaeus, 1758) -, a haris - Crex crex (Linnaeus, 1758)-, az ugartyúk - Burhinus oedicnemus (Linnaeus, 1758) -, a kék vércse (Falco vespertinus Linnaeus, 1766) és a szalakóta (Coracias garrulus Linnaeus, 1758) (Ambrus 1990, Gazdag 2007, Csathó és Csathó 2009, 2011). A madarak tömeges gázolása ritka jelenség, azonban néhány esetben beszámoltak ilyen jellegü pusztulásokról is. Kalotás (1982) és Nagy (1982) is jelentős pintygázolást tapasztalt a téli hónapok során, amelyeknek a nagy része fenyőpinty (Fringilla montifringilla Linnaeus, 1758) volt.

3. táblázat. A közúti gázolások során a tíz legnagyobb, forintban kifejezett természetvédelmi kárt elszenvedett madárfaj Magyarországon a publikált adatok alapján.

\begin{tabular}{ccc}
\hline Magyar név & Tudományos név & Természetvédelmi kár $(\mathrm{Ft})$ \\
\hline Füsti fecske & Hirundo rustica & 12250000 \\
Molnárfecske & Delichon urbicum & 10750000 \\
Kuvik & Athene noctua & 10100000 \\
Mezei veréb & Passer montanus & 9825000 \\
Tövisszúró gébics & Lanius collurio & 6925000 \\
Gyöngybagoly & Tyto alba & 6600000 \\
Fenyöpinty & Fringilla montifringilla & 5925000 \\
Tengelic & Carduelis carduelis & 4175000 \\
Erdei fülesbagoly & Asio otus & 3150000 \\
Fekete rigó & Turdus merula & 1725000 \\
\hline
\end{tabular}




\section{Emlösök (Mammalia)}

A szakirodalmi áttekintés során 15 közleményt találtunk a témával kapcsolatosan. Az emlősök számos élőhelytípusban előfordulnak, így elütött egyedeikkel bárhol találkozhatunk az utak mentén. Az esetek többsége egyéni gázolás, tömeges pusztulásról nem áll rendelkezésre információ. Az összesített adatok alapján 35 emlősfaj „úti halála” volt bizonyított Magyarországon. A legtöbb közölt elütött egyed a rovarevők (Insectivora) és a rágcsálók (Rodentia) rendjéből került elö. A leggyakoribb elgázolt emlős a közölt adatok alapján a keleti sün (Erinaceus roumanicus Barrett-Hamilton, 1900) volt közel 1000 egyeddel (4. táblázat).

Az elütött emlősök fajlistájában 21 természetvédelmi oltalom alatt álló faj szerepel, köztük négy fokozottan védett. Az összesített adatok alapján kb. 1400 egyed elütését regisztrálták, amelynek következtében több mint 90 millió forintnyi természetvédelmi kár keletkezett. A legnagyobb természetvédelmi kár a vidra - Lutra lutra (Linnaeus, 1758) - esetében volt tapasztalható. Összesen 177 elütött

4. táblázat. A tíz leggyakrabban elgázolt emlősfaj Magyarországon a publikált adatok alapján.

\begin{tabular}{ccc}
\hline Magyar név & Tudományos név & Elütött egyedek száma \\
\hline Keleti sün & Erinaceus roumanicus & 958 \\
Mezei hörcsög & Cricetus cricetus & 584 \\
Mezei pocok & Microtus arvalis & 395 \\
Vidra & Lutra lutra & 177 \\
Erdeiegér-fajok & Apodemus spp. & 136 \\
Vándorpatkány & Rattus norvegicus & 70 \\
Molnárgörény & Mustela eversmanii & 44 \\
Házi egér / güzüegér & Mus musculus / Mus spicilegus & 34 \\
Vakond & Talpa europaea & 19 \\
Menyét & Mustela nivalis & 16 \\
\hline
\end{tabular}

egyedet regisztráltak, ami több mint 44 millió forint természetvédelmi kárt jelent (5. táblázat). A természetvédelmi szempontból legértékesebb fajok között megtalálható a vidra mellett a vadmacska (Felis silvestris Schreber, 1775), a közönséges ürge - Spermophilus citellus (Linnaeus, 1766) - és a nyugati földikutya fajcsoport - Nannospalax (superspecies leucodon) Nordmann, 1840 (Gazdag 2007, Csathó és Csathó 2009, Molnár és Andrési 2019, Németh et al. 2021).

Az emlősök közül egyes kisemlős- és dögevő fajok egyedei jelennek meg leggyakrabban az utak mentén táplálékszerzés céljából. Általánosságban elmondható, hogy az emlősök legnagyobb része csak keresztezi az utakat az élőhelyfoltok közötti átjárás során. A keleti sün gyakori elütéséhez hozzájárul, hogy a fajra jellemző védekezési stratégia, az összegömbölyödés, nem csökkenti, hanem inkább növeli az elütés esélyét (Vadonleső Group et al. 2019). 
5. táblázat. A forintban kifejezett, tíz legnagyobb természetvédelmi kárt elszenvedett emlősfaj Magyarországon a publikált adatok alapján.

\begin{tabular}{ccc}
\hline Magyar név & Tudományos név & Természetvédelmi kár (Ft) \\
\hline Vidra & Lutra lutra & 44250000 \\
Keleti sün & Erinaceus roumanicus & 23950000 \\
Mezei hörcsög & Cricetus cricetus & 14600000 \\
Nyugati földikutya fajcsoport & Nannospalax (superspecies & 4000000 \\
Molnárgörény & leucodon) & 2200000 \\
Mogyorós pele & Mustela eversmanii & 650000 \\
Vakond & Muscardinus avellanarius & 475000 \\
Menyét & Talpa europaea & 400000 \\
Erdei cickány & Mustela nivalis & 275000 \\
Keleti cickány & Sorex araneus & 275000 \\
\hline
\end{tabular}

\section{Diszkusszió}

Magyarországon eddig 41 közlemény jelent meg az állat-gázolások témájában, amelyek több tízezer gerincesegyed pusztulásáról számoltak be, aminek következtében több milliárd forintos természetvédelmi kár keletkezett. A tanulmányok döntő része esetleírásokat tartalmaz, amelyek regionális szinten világítottak rá egyes problémás útszakaszokra és elhullásokra. Azonban ez csak a ,jéghegy csúcsa”, mivel az országot teljesen lefedő és kellö időtartamú vizsgálatot még nem végeztek, illetve sok esetben a pusztulások felderítése sem egyszerü. Grilo és munkatársai (2020) modellezés segítségével megbecsülték az európai közúthálózaton elpusztult madarak és emlősök mennyiségét. Eredményeik alapján évente kb. 194 millió madár és 29 millió emlős pusztul el gépjárművekkel való ütközés során Európában. Ha ennek tükrében megvizsgáljuk az úthálózatok arányát, akkor feltételezhetően a Magyarországon elpusztult madarak és emlősök száma is több millió egyedre tehető évente.

A források heterogén jellege és a hiányos adatközlések miatt a magyarországi tanulmányokból messzemenő következtetéseket nem tudtunk levonni, azonban néhány megállapításra szeretnénk felhívni a figyelmet. A közúti forgalom természetkárosító hatása eltérő mintázatokat mutatott a különböző gerinces-osztályoknál. Míg a kétéltủeknél szinte kizárólag csak tömeges pusztulásokat közöltek (Frank et al. 1991, Puky 1987, Puskás 2019, Ursu 2019), addig a többi osztálynál az ilyen jellegü események jóval ritkábbak voltak. A hüllők esetében is tapasztaltak nagyszámú, egy adott rövid útszakaszhoz kötődő elütéseket a vonulási időszak- 
ban, de ezek mértéke nagyságrendekkel kisebb volt a kétéltüekéhez képest (Frank et al. 1991, Szabolcs et al. 2014). A madaraknál három tanulmányban találtunk információt tömeges elhullásokról. Kalotás (1982) és Nagy (1982) nagyszámú pinty pusztulásáról számolt be. Közlésük alapján a madarak a tartós hóborításnak köszönhetően rendszeresen a letakarított utakon és az útszegélyeken táplálkoztak, így fokozottan ki voltak téve a gépjármüvekkel való ütközésnek. E. Nagy (1981) tömeges molnárfecske-pusztulást tapasztalt 1981 júliusában Visegrád térségében. Véleménye szerint a markáns lehülés és esős időjárás következtében a kimerült madarak az úttest közvetlen közelében vadásztak, emiatt estek áldozatul a közúti forgalomnak. A szerző az utóbbi jelenséget az esőzések utáni légnyomáseséssel magyarázta, aminek következtében a molnárfecskék táplálékául szolgáló rovarok is az utak mentén koncentrálódtak. Az emlősök esetében nem találtunk semmilyen tömeges pusztulásra utaló forrást.

A közúti gázolások idő- és térbeli mintázatában is találtunk összefüggéseket a kétéltü- és a hüllö-gázolások között. Egyértelmúen kijelenthetö, hogy ennél a két csoportnál az őszi és tavaszi vonulás során következtek be a legnagyobb mértékủ pusztulások. Emellett a táji környezet is fontos szerepet játszott az elütési gócpontok kialakulásában. A madár- és az emlős-gázolások tekintetében idő- és térbeli mintázatot nem tudtunk meghatározni a publikált adatokból. Mivel ezen taxonok képviselöi megtalálhatók valamennyi magyarországi, utak mentén elöforduló élőhelytípusban, így szinte akárhol találkozhatunk elütött egyedeikkel a magyarországi utakon. Monoki (2005) a nappali ragadozómadarak és a baglyok elütésének legfőbb okát a kisemlősök utak menti nagy egyedszámú populációiban látja. A magas rézsűvel rendelkező utak menedékként szolgálnak a kisemlősök számára. Továbbá a közúti terményszállítás során rendszeresen az utakra hullanak a gazdasági haszonnövények termései, amelyek időszakosan megfelelő táplálékbázist nyújtanak számukra. Utóbbi hatás a magevő énekesmadarak egy részét is az utakra csábíthatja, megnövelve az elütések esélyét. Feltehetöleg az útmenti vegetáció (fák, cserjék, árkok nádasai) is jelentősen befolyásolja a madarak elütésének gyakoriságát (van der Ree et al. 2015). Számos faj választja esetenként ezeket az élettereket fészkelő-, pihenő-, illetve vártahelyül.

A közúti közlekedés mint természetkárosító tényezö hatással van egyes védett és fokozottan védett fajok populációnagyságára. Mátics (2004) a gyöngybagoly - Tyto alba (Scopoli 1769) - gyürúzési-megkerülési adatai alapján kimutatta, hogy a meggyürüzött elpusztult madarak közel 20\%-a a közúti közlekedésnek esett áldozatul. Csathó és Csathó (2009) megvizsgálta a közúti elütések Battonya külterületén fészkelő madárpopulációkra gyakorolt hatását. A térség egyik leggyakoribb fészkelő madárfaja, a tövisszúró gébics (Lanius collurio Linnaeus, 1758) esetében azt állapították meg, hogy a költési időszakban elpusztult adult 
madarak a helyi populáció kb. 3,2\%-át tették ki. Mindemellett az öreg madarak elpusztulása esetén a fiókák kirepülésének esélye is csökkenhet.

\section{Természetvédelmi szempontú kitekintés}

Több országban már évtizedek óta folyik rendszeres adatgyüjtés az utakon elpusztult állatokról. Azon kívül, hogy ezek a vizsgálatok fontos információval szolgálnak az elütött állatok faji hovatartozásáról, egyedszámáról és az okozott természetvédelmi kár mértékéről, más szempontból is értékesek lehetnek a természetvédelem számára. A nemzetközi szakirodalomban több példát is találhatunk arra, hogy az elütések felmérése hozzájárulhat a nehezen megfigyelhetö fajok állománynagyságának becsléséhez és elterjedési területeinek pontosításához. NagyBritanniában a közönséges görény (Mustela putorius Linnaeus, 1758) észleléseinek több mint a felét az utak mentén elpusztult egyedek tették ki (Croose 2016). Csathó és Csathó (2009) a mezei hörcsög (Cricetus cricetus Linnaeus, 1758) populációdinamikai változását követték nyomon az elütésekből származó adatok segítségével Battonya térségében. A rágcsálófaj gradációját érintő időszakokban megfigyelhető volt a molnárgörény (Mustela eversmanii Lesson, 1827) populációjának növekedése is. Az elütött állatok genetikai vizsgálatával megismerhető a populációk genetikai diverzitása, ami különösen fontos a nehezen befogható, de gyakran közúti gázolásra kerülő fajok, mint például a vidra esetében is (Lehoczky et al. 2015). Kivételes esetekben az elütéseknek köszönhetően az adott térség faunájában ritka vagy akár arra új fajok is elökerülhetnek (Safford et al. 1995, Dyczkowski 2016). Magyarországon is volt már erre példa, egy alkalommal egy nyílfarkú halfarkas (Stercorarius longicaudus Vieillot, 1819) elgázolt egyede került elö, ami a faj tizedik hitelesített, magyarországi megkerülését eredményezte (Hadarics 2009). Lengyelországban például a tájidegen fajok állománynövekedési és elterjedési folyamatának kimutatásában nagy szerepe volt az elütés következtében megkerült nyestkutyák - Nyctereutes procyonoides (J. E. Gray, 1834) - adatainak (Kowalczyk et al. 2009). A magyarországi adatsorokban is találhatunk példát inváziós fajok jelenlétére az elütött fajok között, pl. a pézsmapocok - Ondatra zibethicus (Linnaeus, 1766) - „személyében”. Az elütött állatok bizonyos esetekben hozzájárulnak egy faj kórélettanának megértéséhez. Egyes helyszíneken az elütött állatokon laboratóriumi vizsgálatokat is végeznek annak érdekében, hogy különböző betegségeket vagy kemikáliák maradványainak mennyiségét elemezzék bizonyos fajokban. Angliában és Walesben begyüjtött elütött vidrák szövetmintáinak elemzése során kiderült, hogy szervezetükben nagymértékben jelen van egy égésgátló anyag származéka (Pountney et al. 2015). Magyarországon Lanszki et al. (2007) kutatásában vidrák post mortem vizsgálatát végezték el, a tetemek mintegy 90\%-a közúti gázolásból származott. Heys és munkatársai 
(2017) az 1979 és 1990 között elgázolt karvalyoktól - Accipiter nisus (Linnaeus, 1758) - származó agyszövet-mintákat elemezték peszticid-származékok kimutatása érdekében. Fenti példák alapján az elütött állatok vizsgálata számos módon járulhatna hozzá a magyarországi ökotoxikológiai, invázióbiológiai és állategészségügyi kutatásokhoz. Egyes esetekben akár müködőképes monitoring-rendszert is ki lehetne építeni ezen kérdések vizsgálatára.

A civilizáció jelentős terhet ró az élővilágra, amely hatások nagymértékben befolyásolják az állatokat és életterüket. Annak érdekében, hogy ezt a negatív hatást mérsékelni tudjuk, szükség van minél átfogóbb monitoring-rendszer felállítására. Magyarországon több szervezet (nemzeti parkok, civil egyesületek) gyüjt elütésekkel kapcsolatos adatokat, azonban ezek feldolgozása háttérbe szorul, illetve az eltérő felmérési módszerek miatt elemzésük sokszor nehézkes. Szükség lenne életre hívni egy monitorozó hálózatot az elütések felmérésére, amelyen belül egységes módszerekkel, országos szinten lehetne gyüjteni az adatokat. Ezáltal pontosabb képet kaphatnánk arról, hogy az állatok gépjármúvekkel történő ütközése mekkora természetvédelmi problémát jelent. Már 12 országban vontak be civileket is az adatgyüjtésbe különböző digitális platformok segítségével egészen jó hatásfokkal (Waetjen és Shilling 2017). A „citizen science” keretén belül már Magyarországon is múködnek olyan kezdeményezések, amely közismert fajokról többek között gázolási adatokat is gyüjtenek (http6, http7). A Vadonleső projekt többéves felmérésének köszönhetően sikerült például az urbanizálódott keleti sün állományokat felmérni Budapesten és vonzáskörzetében, illetve felderíteni az elütésekkel kapcsolatos „hotspot”-okat (Vadonleső Group et al. 2019).

A publikált eredmények jól tükrözik, hogy a közúti közlekedés természetkárosító hatása nem új keletü, de annál inkább jelentős mértékü természetvédelmi probléma Magyarországon is. Az állatok megóvása érdekében már évtizedek óta zajlanak természetvédelmi célú beruházások és mentőakciók országszerte. A kétéltüek és hüllők vonatkozásában több sikeres projektről is számot adtak, ahol több tízezres nagyságrendben sikerült megmenteni az említett két taxon egyedeit. Puskás (2019) a békaalagutak hatékony müködéséről, míg Puky (1987) és Ursu (2019) a mentőakciók kiemelkedő természetvédelmi szerepéről tesz említést. A madarak és emlősök terén már nehezebb feladata van a természetvédelemnek, de ezen taxonok védelmére is alkalmaznak különböző védelmi berendezéseket (madárfal, vadkerítés, vadátjáró stb.). Részletesebb vizsgálatok eredményeinek segítségével és a társadalmi tudatformálás eszközével további előrelépéseket lehetne tenni annak érdekében, hogy mérsékeljük az állatvilág és a civilizáció között kialakuló konfliktushelyzeteket. 
Köszönetnyilvánitás - A cikk az Innovációs és Technológiai Minisztérium Kooperatív Doktori Program doktori hallgatói ösztöndíj programjának a Nemzeti Kutatási, Fejlesztési és Innovációs alapból finanszírozott szakmai támogatásával készült (KDP-2020-967901). Köszönjük az NKFI FK 124404 (VO) és az NTP-NFTÖ-21-B-0095 (GL) pályázat támogatását.

\section{Irodalomjegyzék}

Ambrus, B. (1990): Gépjárművek okozta madárpusztulások Kömlő és Hevesvezekény közötti útszakaszon 1989.06-08. hónapokban. Madártani Tájékoztató 1990(3-4): 16-17.

Barnes, M. D. (1936): The death-roll of birds on our roads. Naturalist 1936: 85-86.

Croose, E. (2016): The distribution and status of the polecat (Mustela putorius) in Britain 20142015. The Vincent Wildlife Trust, Ledbury, 65 p.

Csathó, A. I., Csathó, A. J. (2009): Elütött állatok Battonyán. CSEMETE Természet- és Környezetvédelmi Egyesület, Battonya - Szeged, 63 p.

Csathó, A. I., Csathó, A. J. (2011): Elütött állatok felmérése Battonya város közútjain. In: Tóth, M., Puky, M. (szerk.): Vonalas létesitmények és élövilág: Hogyan létezhetnek egymás mellett? Vonalas létesitmények IENE Mühelytalálkozó. Program és összefoglalók. Magyar Biológiai Társaság Környezet- és Természetvédelmi Szakosztály, Varangy Akciócsoport Egyesület, Budapest, pp. $10-11$.

Csathó, A. I., Csathó, A. J. (2014): Az idén huszadik éves battonyai elütöttállat-felmérés legutóbbi öt évének (2010-2014) adatai. In: Lengyel, Sz. (szerk.): IX. Magyar Természetvédelmi Biológiai Konferencia - ,Tudományoktól a döntéshozatalig”, absztrakt-kötet. Magyar Biológiai Társaság, Szegedi Tudományegyetem Ökológiai Tanszék, MTA Ökológiai Kutatóközpont, Szeged, pp. 45-46.

Cserkész, T., Farkas, J., Ottlecz, B. (2012): Közlekedési áldozatok a természetből - A vadelütésről tárgyilagosan. Élet és Tudomány 67(9): 269-271.

Cserkész, T., Ottlecz, B., Cserkész-Nagy, Á., Farkas, J. (2013): Interchange as the main factor determining wildlife-vehicle collision hotspots on the fenced highways: spatial analysis and applications. European Journal of Wildlife Research 59(4): 587-597. https://doi.org/10.1007/s10344013-0710-2

Dyczkowski, J. (2016): Golden nightjar in western Sahara, Morocco, in May 2015. Dutch Bird 38: $80-86$.

E. Nagy, L. (1981): Madárpusztulás a közutakon. Madártani Tájékoztató 1981(4): 198-199.

Endes, M. (1990): Kígyót, békát. Calandrella 4(1): 110-111.

Faragó, S., László, R. (2002): Gépjármü-vad ütközés okozta vadelhullások a magyar vadállományban. Nimród 90(2): 20-22.

Fenyves, L. (1989): Gerinces állatok pusztulása az utakon. Madártani Tájékoztató 1989(1-2): 54 55 .

Frank, T., Pellinger, A., Selyem, J. (1991): Kétéltü (Amphibia) és hüllő (Reptilia) védelem a Fertőtó mentén (1987-1990): A Magyar Madártani és Természetvédelmi Egyesület III. Tudományos Ülése Évkönyve, Szombathely, pp. 330-337.

Gazdag, F. (2007): A közúti közlekedés, mint természetkárosító tényezö. Magyar Vadászlap 2007(8): 476-477.

Gazdag, F. (2008): Autós vámszedők. A száguldás áldozatai. Természetbúvár 63(1): 40. 
Grilo, C., Koroleva, E., Andrášik, R., Bíl, M., González-Suárez, M. (2020): Roadkill risk and population vulnerability in European birds and mammals. Frontiers in Ecology and the Environment 18(6): 323-328. https://doi.org/10.1002/fee.2216

Hadarics, T. (2009): Érdekes madármegfigyelések (2009. augusztus-október). Madártávlat 2009(4): 32.

Hill, J. E., DeVault, T. L., Belant, J. L. (2019): Cause-specific mortality of the world's terrestrial vertebrates. Global Ecology and Biogeography 28(5): 680-689. https://doi.org/10.1111/geb.12881

Hodson, N. L., Snow, D. W. (1965): The road deaths enquiry, 1960-61. Bird Study 12(2): 90-99. https://doi.org/10.1080/00063656509476091

Ibisch, P. L., Hoffmann, M. T., Kreft, S., Pe'er, G., Kati, V., Biber-Freudenberger, L., Selva, N. (2016): A global map of roadless areas and their conservation status. Science 354 (6318): 14231427. https://doi.org/10.1126/science.aaf7166

Kalotás, Zs. (1982): Tömeges madárpusztulás az utakon. Madártani Tájékoztató 1982(2-3): 132133.

Krug, T. (1983): Autók által okozott madár- (és egyéb állat-) pusztulások 1982-ben. Madártani Tájékoztató 1983(3-4): 80.

Lanszki, J., Sugár, L., Orosz, E. (2007): Hazai vidrák morfológiai jellemzői és elhullási okai post mortem vizsgálat alapján. Állattani Közlemények 92(1): 67-76.

Lehoczky, I., Dalton, D. L., Lanszki, J., Sallai, Z., Madisha, M. T., Nupen, L. J., Kotzé, A. (2015): Assessment of population structure in Hungarian otter populations. Journal of Mammalogy 96(6): 1275-1283. https://doi.org/10.1093/jmammal/gyv136

Mátics, R. (2004): A gyöngybagoly (Tyto alba) természetes és nem természetes mortalitása: nő az utakon történő pusztulás jelentősége. Természetvédelmi Közlemények 11: 517-524.

Molnár, Gy., Andrési, P. (szerk.) (2019): A civilizáció káros hatásai az élővilágra Magyarországon. Typotex Kiadó, Budapest, 297 p.

Monoki, Á. (2005): Lőtt rétisas mentése Kunhegyes határában. Zöld Híradó 9(6): 5.

Nagy, S. (1982): Madárpusztulások Dombóvár környékén. Madártani Tájékoztató 1982(4): 274275.

Németh, A., Schneider, V., Váczi, O., Csorba, G. (2021).: Felszínen mozgó földikutyák - A földikutyák védelmének új kihívása. Természetvédelmi Közlemények 27: 36-54. https://doi. org/10.20332/tvk-jnatconserv.2021.27.36

Onuczán, J. (1992): Elpusztult gerinces állatok az úttesten. Madártani Tájékoztató 1992(1-2): 4.

Pallag, O. (szerk.) (2000): Nyomvonalas létesitmények élöhely-fragmentáló hatása. Környezetgazdálkodási Intézet, Budapest, 107 p.

Puky, M. (1987): Varangy akció. Természetvédelem 17: 22-23.

Puky, M., Schád, P., Szövényi, G. (2005): Magyarország herpetológiai atlasza. Varangy Akciócsoport Egyesület, Budapest, 207 p.

Puskás, J. (2019): Kétéltű fajok és vidrák gázolási nagyságrendje Szeged környéki közutakon. In: Molnár, Gy., Andrési, P. (szerk.): A civilizáció káros hatásai az élövilágra Magyarországon. Typotex Kiadó, Budapest, pp. 132-133.

Safford, R. J., Ash, J. S., Duckworth, J. W., Telfer, M. G., Zewdie, C. (1995): A new species of nightjar from Ethiopia. Ibis 137(3): 301-307. https://doi.org/10.1111/j.1474-919X.1995.tb08025.X

Schwartz, A. L., Shilling, F. M., Perkins, S. E. (2020): The value of monitoring wildlife roadkill. European Journal of Wildlife Research 66(1): 1-12. https://doi.org/10.1007/s10344-019-1357-4

Szabolcs, M., Zsólyomi, T., Lengyel, Sz. (2014): Kígyók közúti pusztulása a Bodrog-folyó mentén. In: IV. Herpetológiai Elöadóülés. Elöadások összefoglalói. Magyar Természettudományi Múzeum, Magyar Biológiai Társaság Állattani Szakosztálya, Magyar Madártani- és Természetvédelmi Egyesület Kétéltü- és Hüllővédelmi Szakosztálya, Budapest, p. 21. 
Träger, J. (1978): Gépkocsik által elgázolt állatok. Madártani Tájékoztató 1978(3): 17-18.

Ursu, D. B. (2019): Az utakon történt békaelütések tapasztalatai és megelőzésük lehetőségei Farmoson. In: Molnár, Gy., Andrési, P. (szerk.): A civilizáció káros hatásai az élővilágra Magyarországon. Typotex Kiadó, Budapest, pp. 139-140.

Vadonleső Group, Brendt, M., Lukács, A., Oláh, B. K., Farkas, A. (2019): Urban hedgehogs (Erinaceus roumanicus) in Budapest: live or let die. Hungarian Agricultural Research 28(3): 20-26. van der Ree, R., Smith, D., Grilo, C. (2015): Handbook of Road Ecology. Wiley-Blackwell, Oxford, $552 \mathrm{p}$.

Waetjen, D. P., Shilling, F. M. (2017): Large extent volunteer roadkill and wildlife observation systems as sources of reliable data. Frontiers in Ecology and Evolution 5: 89. https://doi. org/10.3389/fevo.2017.00089

\section{Hivatkozott jogszabályok:}

66/2015. (X. 26.) FM rendelet az elkobzott védett természeti értékekkel kapcsolatos intézkedésekröl szóló 19/1997. (VII. 4.) KTM rendelet, valamint a védett és a fokozottan védett növény- és állatfajokról, a fokozottan védett barlangok köréről, valamint az Európai Közösségben természetvédelmi szempontból jelentős növény- és állatfajok közzétételéről szóló 13/2001. (V. 9.) KöM rendelet módosításáról.

\section{Internetes források:}

http 1: https://carsguide.com

http2: https://www.ksh.hu

http3: https://matarka.hu

http4: https://scholar.google.com

http5: https://webofscience.com

http6: https://vadonleso.hu

http7: https://herpterkep.mme.hu/

\section{Függelék:}

A cikkhez tartozó Online Függelékek a folyóirat honlapján találhatók.

1. Online Függelék: Az adatelemzéshez felhasznált publikációk listája.

2. Online Függelék: A Magyarországon publikált elütési adatokkal rendelkező gerincesfajok listája. 


\title{
Negative effects of traffic on vertebrate species - A literature review from Hungary
}

\author{
Sándor Borza ${ }^{1,2,3^{*}}$, Laura Godó ${ }^{1}$, András István Csathó ${ }^{4}$, \\ Orsolya Valkó ${ }^{1} \&$ Balázs Deák ${ }^{1}$ \\ ${ }^{1}$ Centre for Ecological Research, Institute of Ecology and Botany, Lendület Seed Ecology \\ Research Group, H-2163 Vácrátót, Alkotmány u. 2-4, Hungary \\ ${ }^{2}$ University of Debrecen Juhász-Nagy Pál Doctoral School, \\ H-4032 Debrecen, Egyetem tér 1, Hungary \\ ${ }^{3}$ Hortobágy National Park Directorate, H-4024 Debrecen, Sumen u. 2, Hungary \\ ${ }^{4}$ Independent researcher, H-5830 Battonya, Somogyi Béla u. 42/A, Hungary \\ ${ }^{*} E$-mail: borzas89@gmail.com
}

Traffic is one of the most important pillars of economy and is a central factor of our everyday lives. In the past decades, the expanse of road networks and the number of vehicles increased considerably all over the world. These effects pose a serious threat to the wildlife, and generates conflicts between humans and the wildlife, including animal-vehicle collisions have become a major problem. In our review, we surveyed the related publications from Hungary in order to identify the negative effects of traffic on vertebrates. We found 41 articles related to animal-vehicle collisions, which list a total of 153 vertebrate species involved in roadkill. The nature conservation damage caused by the roadkills exceeded one billion HUF in the case of the vertebrate fauna in Hungary.

Keywords: animal-vehicle collision, roadkill, road mortality, nature conservation damage, habitat fragmentation, Amphibia, Reptilia, Aves, Mammalia 